\title{
Now Hear This!
}

\section{Incorporating Early Literacy Messages into Storytimes}

\author{
BY MELISSA DEPPER
}

I $n$ response to the release of the updated and expanded 2nd edition of Every Child Ready to Read (ECRR2), as well as feedback from our storytime providers, in 2012 the Arapahoe (CO) Library District revised its five-year-old method for supporting and enabling storytime providers to provide early literacy messages to parents and caregivers during storytimes.

In 2007, we began training storytime providers on the six ECRR early literacy skills and expected that each provider would deliver an early literacy message or tip to adults each storytime. We created a calendar so that each month our patrons would all hear messages about the same skill (February = Vocabulary, March = Phonological Awareness, and so on), shared resources (such as Saroj Ghoting and Pamela Martin-Díaz's Early Literacy Storytime: Partnering with Caregivers for Success), and provided sample tips for all skills and age groups.

Our new strategy, launched in early 2012, was developed in response to our providers' need both for more early literacy instruction and for more support in creating and providing effective early literacy messages. In addition to providing verbal tips, we wanted to make an even stronger commitment to explicitly modeling early literacy behaviors and activities to adults during storytime, with the goal of making it even easier for parents and caregivers to see the connections between what they do and what their children learn. The release of ECRR2 gave us a timely platform and fresh material to use in redesigning our approach.

We named our early literacy component the Parent Literacy Connection, and it consists of two parts - an activity (book, song, rhyme, fingerplay, flannelboard, game, and so on) designed for the children and supporting an early literacy skill or practice and a conversational, brief, early literacy message delivered to the adults.
Everything we do in storytime supports early literacy development, but this is the moment in which we talk directly to parents and caregivers about what we do and why we do it. And it's all about building connections and relationships between the storytime provider and the adults, as well as drawing connections between the activities and the early literacy skills those activities develop.

We felt the message would be more effective when paired immediately before or after an activity that modeled it, rather than shared separately before or after storytime. Learning is more effective, for both children and adults, when we are involved and engaged with the material, rather than when we are told something out of immediate context.

We provided a template for storytime providers to use, rather than inviting them to create their own messages. These templates allowed us to save time, increase confidence, support listeners, and encourage consistency. Our template has four parts, each designed for a particular purpose.

The Activity Statement provides a natural transition from a storytime activity to the literacy message. It draws the parents'

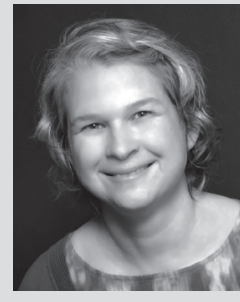

Melissa Depper is a Librarian for the Arapahoe (CO) Library District, where she works primarily with early childhood programs and services and develops and leads staff training for storytime providers. She serves on the ALSC Children and Technology Committee. 
and caregivers' attention to the component just completed (or just about to begin) - a book, song, rhyme, fingerplay, flannelboard, or game. The phrasing "When you. . . was chosen to remind adults that they already do-or could do-similar activities with their children, and to celebrate and emphasize that involvement.

The Skill Statement lets parents know that what they do with their children makes a difference-that every conversation, game, song, art project, or book they share together results in learning and development. Children are always learning and growing across multiple domains, but in a library setting, the domains in which we are most invested concern early literacy. This statement makes a connection from storytime activities to early literacy learning by introducing concepts about early literacy skills.

As much as we appreciate the presentation of ECRR's five practices (reading, writing, singing, talking, and playing) as a way to introduce early literacy to parents and caregivers, we didn't want to let go of all of the six skills (print awareness, print motivation, letter knowledge, vocabulary, narrative skills, and phonological awareness).

The Good Readers Statement gives parents and caregivers the "wheels on the ground" practical outcome of building early literacy skills. We don't want to give parents a laundry list of things to do-they have plenty to do already-without helping them understand more about why and how those activities help their children. This part of the template shows specifically how the broad concepts referred to in the Skill Statement (comprehension, alphabetic principle, phonological awareness, etc.) help children become successful readers. When we understand a concept and have a rationale for applying it, we are much more likely to adjust our behaviors. The Good Readers Statement provides meaning, context, and motivation to parents and caregivers.

The Practice Statement reinforces the "practice of the month" for the parents and caregivers, and it provides consistent, recognizable closure to the literacy message. Just as in the past, we organized a district-wide focus on one early literacy skill every month, so now we highlight one practice every month at every branch. If parents and caregivers are distracted and don't hear the details of the literacy message one week, they will still be consistently exposed to simple, powerful messages that reading, writing, singing, talking, and playing with their children will help them get ready to read.

The four-part literacy message template is a core element in our early literacy storytimes. To assist staff in delivering this message, we have provided support via articles written for a district-wide monthly e-newsletter, now archived on the staff Intranet, making connections between the five practices and the six early literacy skills. Additional support was provided by the creation of more than eighty handouts (also archived on the staff Intranet) providing suggestions for storytime activities that support early literacy and literacy messages created with the template that go along with the activity; each handout also has a paragraph of background information, summarizing recent research or expanding on basic early literacy concepts.

Using a literacy message template allows the Arapahoe Library District to provide continuing education support to our staff and respect their time management needs as we present robust early literacy activities and messages to our families. It accommodates both new and experienced storytime providers, and, most importantly, allows families to benefit from a consistent format. $£$

\section{Sample Activity and Message Pairs (continued on following page)}

\begin{tabular}{|c|c|}
\hline Storytime Activity & Literacy Message \\
\hline $\begin{array}{l}\text { Display and promote song picturebooks from the } E 782.42 \text { section } \\
\text { during your storytime, or read and sing a book from this section. }\end{array}$ & $\begin{array}{l}\text { Parents, when you use picturebooks to share and sing familiar songs, your } \\
\text { children learn that the things they love can be found in books. This helps } \\
\text { motivate them to become good readers because they know books contain } \\
\text { things they like. Singing with your children helps them get ready to read. }\end{array}$ \\
\hline Practice: Singing & Skill: Print Motivation \\
\hline $\begin{array}{l}\text { Sing an "animal noises" song in storytime, like "Old MacDonald Had a } \\
\text { Farm," or "When Ducks Get Up in the Morning," or "Fiddle-l-Fee." }\end{array}$ & $\begin{array}{l}\text { Parents, when you sing songs with animal sounds in them, your children } \\
\text { are really learning to hear the sounds PEOPLE say. This will help them } \\
\text { become good readers because being able to hear all these sounds } \\
\text { helps them sound out words when they read. Singing with your children } \\
\text { will help them get ready to read. }\end{array}$ \\
\hline Practice: Singing & Skill: Phonological Awareness \\
\hline $\begin{array}{l}\text { Play a sorting game with the children-give them construction paper } \\
\text { shapes and ask them to bring up all of the squares, then the triangles, } \\
\text { and so on. You could also sort clip art pictures to match your theme- } \\
\text { different kinds of bugs, or things that go. }\end{array}$ & $\begin{array}{l}\text { Parents, when you talk about same and different with your children, they } \\
\text { start to learn how to compare things themselves. This helps them be good } \\
\text { readers because they will use the same skills to learn the differences in } \\
\text { letter shapes! Talking with your children will help them get ready to read. }\end{array}$ \\
\hline Practice: Talking & Skill: Letter Knowledge \\
\hline
\end{tabular}




\section{Storytime Activity}

Make toilet paper tube "binoculars" for the children in your storytime, or just look through your cupped hands as pretend binoculars. Ask them to look around the room and discover something that they see-then have them describe what they're looking at to their grown-up.

Practice: Talking

Hand out scarves (or ribbons, or "magic wands") to the children, and have them do what you do. Babies and parents can move their scarves up, down, and around. Toddlers can make rainbows (arcs), circles, or zigzags. PreKs can follow along as you make letter shapes ("Let's start up here and make a big swoop down and around for a C!")

Practice: Writing

Make a list on a whiteboard or poster paper of objects or ideas from one of your books, songs, or activities. You might list all the things Pete the Cat steps in, or all the animals in your version of Old MacDonald. Have the children help you build the list, then read it back to them when you're done.

Practice: Writing

Pretend you don't know how to hold a book or where to start reading it. Hold it upside down and backwards, then let the children correct you! If they don't, then correct yourself. "I can't read the book like this!" Try to open up the spine, turn to the last page first, and so forth.

Practice: Playing

Tell "Going on a Bear Hunt" twice-once with you leading, and once with the kids telling you what comes next and acting it out. Use flannel pieces or other props as visual cues.

Practice: Playing

For one of your books, think of two or three open-ended questions to ask during the course of your reading. One technique is to put your questions on sticky notes on the back cover!

Practice: Reading

Read a rhyming book to the children.

Practice: Reading

\section{Literacy Message}

When you take turns describing what you see with your children, you are giving them a chance to hear new words and practice the words they already know. This will help them become good readers because kids with big vocabularies have an easier time recognizing words as they read. Talking with your children will help them get ready to read!

Skill: Vocabulary

Grown-ups, when you and your kids play with scarves or ribbons or magic wands, your children are building strong arm muscles and starting to learn about lines and shapes. These muscles and ideas will help them when they are learning to write. Playing with your children will help them get ready to read and write.

Skill: Letter Knowledge

Parents, when you make lists of interesting things with your children, it gives them a different way to think about and learn new words. This helps them become good readers because kids encounter words in many different ways when they read. Writing with your child will help them get ready to read.

Skill: Vocabulary

Grown-ups, when you explore the book itself with your children, they learn not just the story inside but how the book works. Kids who know how to hold and use books before they go to school can start right away learning how to become good readers. Playing with your children helps them get ready to read.

Skill: Print Awareness

Grown-ups, when you act out a story with your children, they learn how to put story events in order. This helps them become good readers because understanding sequence is a comprehension skill. Playing with your children helps them get ready to read.

Skill: Narrative Skills

Parents, remember when I asked the kids ? When you ask questions that don't have a yes and no answer, it helps children learn to use new words and to think about what they're reading. This will build their comprehension skills and help them become good readers. Reading with your children will help them get ready to read.

Skill: Narrative Skills

Grown-ups, when you read rhyming books to your children, they learn to hear how rhyming words sound the same at the end and different at the beginning. Hearing the separate sounds in words helps good readers sound words out when they read. Reading with your children will help them get ready to read.

Skill: Phonological Awareness 